\title{
ECONOMICA
}

Journal of Economic and Economic Education Vol.2 No.1 (11- 21)

\section{PENGARUH PERHATIAN DAN TINGKAT PENDAPATAN ORANG TUA TERHADAP HASIL BELAJAR EKONOMI SISWA KELAS XI DI SMA NEGERI 12 SIJUNJUNG}

\author{
Asli Darnis \\ Mahasiswa Program Studi Pendidikan Ekonomi STKIP- PGRI Sumbar \\ Jl. Gunung Pangilun No.1, Padang Sumatera Barat \\ Email: darnis.12@yahoo.com \\ Citra Ramayani \\ Dosen Program Studi Pendidikan Ekonomi STKIP- PGRI Sumbar \\ Jl. Gunung Pangilun No.1, Padang Sumatera Barat \\ Email: citra berkatindo@yahoo.co.id
}

Submited: 2013.08.25 Reviewed:2013.09.21 Accepted: 2013.10.13

http://dx.doi.org/10.22202/economica.2013.v2.i1.212

\begin{abstract}
The purpose of this study was to observe the effect of parental income and parental level on learning outcomes in economy class XI SMA 12 Sijunjung school year 2012/2013. This type of research is quantitative. The population in this study were all students of class XI in SMA 12 Sijunjung many as 49 people. The instrument used in this study was a questionnaire. Data analysis is used in two ways : 1) descriptive analysis, and 2) inductive analysis.The results showed that : the first concern of parents of learning outcomes in economy class XI SMA 12 Sijunjung significantly to the value of $t_{-}$( count) $>t_{-}$tabel ie $3.217>2.021$, and sig $0.002<0.05$ then Ho is rejected and Ha accepted. The second level of parental income on learning outcomes economy class $X I$ student at SMAN 12 Sijunjung significantly to the value of $t_{-}$( count) > t_tabel ie $7.609>2.021$, and sig $0.000<0.05$ then Ho is rejected and Ha accepted. The third concern and income level of parents of learning outcomes in the economy class XI SMA 12 Sijunjung significantly to the value of $F_{-}$( count ) > $F_{-}($table ) is $39.276>3.23$ and sig $0.000<0.05$ then Ho is rejected and Ha accepted. Contributions of attention and income of parents of the results of the economic study in class XI Sijunjung SMA 12 is 0.631 or $63.1 \%$. Parental concern and the level of parental income is an important factor that can affect student learning outcomes in economic subjects. Contribution of this study is that parents pay more attention to their children about the issue kependidikannya, in order to increase student learning outcomes.
\end{abstract}

\section{Abstrak}

Tujuan penelitian ini adalah untuk melihat pengaruh perhatian orang tua dan tingkat pendapatan orang tua terhadap hasil belajar ekonomi siswa kelas XI di SMA Negeri 12 Sijunjung tahun pelajaran 2012/2013. Jenis penelitian yang digunakan adalah kuantitatif. Populasi pada penelitian ini adalah seluruh siswa kelas XI di SMA Negeri 12 Sijunjung sebanyak 49 orang. Instrumen yang digunakan dalam penelitian ini adalah berupa angket. Analisis data digunakan dengan dua cara yaitu: 1) analisis deskriptif, dan 2) analisis induktif. Hasil penelitian menunjukan bahwa: pertama perhatian orang tua terhadap hasil belajar ekonomi siswa kelas XI di SMA Negeri 12 Sijunjung berpengaruh signifikan dengan nilai $t_{\text {hitung }}>t_{\text {tabel }}$ yaitu 2,819 $>2,021$, dan sig $0,072<0,05$ maka Ho ditolak dan Ha diterima. Kedua tingkat pendapatan orang tua terhadap hasil belajar ekonomi siswa kelas XI di SMA Negeri 12 Sijunjung berpengaruh signifikan dengan nilai $t_{\text {hitung }}>t_{\text {tabel }}$ yaitu 7,131 > 2,021, dan sig 0,000<0,05 maka Ho ditolak dan Ha diterima. Ketiga perhatian dan tingkat pendapatan orang tua terhadap hasil belajar ekonomi siswa kelas XI di SMA Negeri 12 Sijunjung berpengaruh signifikan dengan nilai $F_{\text {hitung }}>F_{\text {tabel }}$ yaitu 39,276 > 3,23 dan sig 0,000 < 0,05 maka Ho ditolak dan Ha diterima. Sumbangan yang diberikan oleh perkatian dan pendapatan orang tua terhadap hasil belajar ekonomi siswa kelas XI di SMA Negeri 12 Sijunjung adalah 0,631 atau 63,1\%. Perhatian orang tua dan tingkat pendapatan orang tua merupakan faktor penting yang dapat mempengaruhi hasil belajar siswa dalam mata pelajaran ekonomi.

Keywords : Attention Effect, Income Parents, Student Learning Outcomes (C)2013 Prodi Pendidikan Ekonomi STKIP PGRI, Padang 


\section{PENDAHULUAN}

Hasil belajar merupakan salah satu hal yang harus diperhatikan oleh orang tua. Ada beberapa faktor yang dapat mempengaruhi pencapaian hasil belajar anak. Menurut Sunarto (2009: 32) faktorfaktor yang mempengaruhi hasil belajar anak yaitu, faktor Intern dan faktor ekstern. Faktor intern adalah faktor-faktor yang berasal dari dalam diri seseorang yang dapat mempengaruhi prestasi belajarnya. Diantara faktor-faktor intern yang dapat mempengaruhi hasil belajar seseorang antara lain adalah kecerdasan/intelegensi, bakat, minat, dan motivasi. Sedangkan faktor ekstern adalah faktor-faktor yang dapat mempengaruhi hasil belajar seseorang yang sifatnya berasal dari luar diri seseorang tersebut. Yang termasuk faktor-faktor ekstern antara lain: keadaan lingkungan keluarga, lingkungan sekolah, dan lingkungan masyarakat.

Sedangkan menurut Slameto (2003: 54) faktor faktor yang mempengaruhi belajar juga dapat digolongkan menjadi dua yaitu, faktor intern dan faktor ekstern. Faktor intern antara lain faktor jasmaniah, psikologis dan faktor kelelahan, sedangkan faktor ektern antara lain, faktor keluarga, sekolah dan masyarakat.

Salah satu dari faktor faktor yang mempengaruhi hasil belajar anak adalah lingkungan keluarga, oleh sebab itu orang tua perlu mengetahui faktor faktor yang dapat mempengaruhi proses belajar pada anak mereka, sehingga orang tua dapat mengenali penyebab dan pendukung anak dalam berprestasi atau mencapai hasil belajar yang memuaskan.Persentase hasil belajar anak dalam mata pelajaran ekonomi adalah sebagai berikut ini:

Dari tabel 1 terlihat bahwa masih ada nilai siswa yang belum tuntas persentase nilai siswa terendah atau yang belum tuntas pada semester satu 39,42\%, semester dua $26,76 \%$, semester tiga $16,67 \%$, semester empat $0,00 \%$, semester lima $22,92 \%$, semester enam $6,25 \%$. Rendahnya nilai siswa ini diduga dipengaruhi oleh perhatian, Pendidikan, Profesi, dan pendapatan orang tua, maka muncul ide yang mendorong diadakannya penelitian ini.

Tabel 1. Persentase Hasil Belajar Anak dalam Mata Pelajaran Ekonomi di SMA N 12 Sijunjung

\begin{tabular}{clcccc}
\hline No & Semester & KKM & Nilai Tuntas & Nilai Tidak Tuntas & $\begin{array}{c}\text { Persentase Nilai } \\
\text { Terendah }\end{array}$ \\
\hline 1 & Satu & 70 & 43 & 28 & $39,42 \%$ \\
2 & Dua & 70 & 52 & 19 & $26,76 \%$ \\
3 & Tiga & 70 & 40 & 8 & $16,67 \%$ \\
4 & Empat & 70 & 48 & 0 & $0,00 \%$ \\
5 & Lima & 70 & 37 & 11 & $22,92 \%$ \\
6 & Enam & 70 & 45 & 3 & $6,25 \%$ \\
\hline
\end{tabular}

Sumber: Tata usaha SMA N 12 Sijunjung tahun 2013

Dari segi perhatian orang tua, Perhatian dapat dikatakan sebagai pemusatan kegiatan yang ditujukan pada suatu objek (Soemanto 2006: 34). Perhatian orang tua adalah pemusatan energi yang disengaja, dan terkonsentrasi dari orang tua yang dilandasi dari rasa penuh kesadaran, tanggung jawab, dan kasih sayang demi tercapainya hasil belajar

yang memuaskan. Dalam hal ini perhatian orang tua ditujukan pada kegiatan hasil belajar siswa. Pengawasan dan arahan dari orang tua akan berpengaruh terhadap siswa 
dalam mengikuti kegiatan belajar disekolah.

Menurut Winkel (1987:100) perhatian diartikan konsentrasi, yaitu pemusatan tenaga dan energi psikis dalam menghadapi suatu obyek. Kemudian Walgito (1990:56) mengatakan, bahwa perhatian merupakan pemusatan atau konsentrasi dari seluruh aktivitas individu yang ditujukan kepada sekumpulan obyek. Pemusatan yang ditujukan kepada objek yang dimaksud disini adalah mendampingi anak saat belajar, memperhatikan anak saat belajar, memberikan pengarahan pada anak, memberikan peringatan pada anak, melakukan kontrol pada aktivitas belajar anak, memberikan dukungan kepada anak, memberikan penghargaan kepada anak, menjadi teladan yang baik, memberikan perlakuan yang adil terhadap anak, terkendalikan oleh orang tua sehingga anak bisa belajar dengan baik dan mendapatkan hasil belajar yang memuaskan

Menurut Ahmadi (2007:235), lingkungan keluarga merupakan awal perkembangan kepribadian anak dibentuk. Orang tua merupakan motivasi anak untuk meningkatkan hasil belajarnya. Melalui bimbingan dan pengarahan yang diberikan oleh kedua orang tua juga keluarga ikut mempengaruhi semangat anak untuk belajar, agar dapat hasil yang memuaskan. Adanya komunikasi antar pribadi yang baik antara anak dengan anggota keluarga dapat meningkatkan minat dan motivasi anak dalam belajar. Guna meningkatkan hasil belajar siswa tersebut harus ada perhatian dari orang tua yang selalu mengontrol terhadap kebutuhan anaknya berikut juga dengan fasilitas yang disediakan oleh orang tua terhadap anaknya.
Dalam memenuhi fasilitas yang dibutuhkan oleh anak erat hubungannya dengan Pendapatan orang tua. Pendapatan orang tua merupakan suatu kedudukan atau posisi seseorang dalam lapisan masyarakat. Tinggi rendahnya pendapatan seseorang dalam masyarakat dapat ditinjau dari berbagai sudut pandang masyarakat di tempat individu itu tinggal. Terlebih lagi faktor pendapatan orang tua yang mewujudkan pada kemampuan finansialnya. Menurut Sumardi dan Evers (1993:323), pendapatan adalah jumlah penghasilan riil seluruh anggota keluarga yang disumbangkan untuk memenuhi kebutuhan bersama maupun perorangan dalam keluarga.

Dengan demikian dapat disimpulkan bahwa kemampuan finansial orang tua, tentunya akan mempengaruhi fasilitas belajar yang disediakan oleh orang tua terhadap sarana dan prasarana yang dibutuhkan oleh seorang siswa untuk meningkatkan hasil belajarnya. Kemampuan finansial yang berbeda-beda sedikit banyak akan berpengaruh terhadap hasil belajar siswa.

Peneliti menduga hasil belajar siswa dipengaruhi oleh pendapatan orang tua siswa, ada pendapatan orang tua siswa yang tinggi sehingga dapat memenuhi kebutuhan belajar dan sekolah anaknya dan sebaliknya ada pendapatan orang tua siswa yang rendah sehingga kurang mampu memenuhi kebutuhan belajar dan kebutuhan sekolah anaknya sehingga dapat mempengaruhi hasil belajar anaknya. Dengan demikian keberhasilan seorang siswa dalam pendidikannya erat kaitannya dengan pendapatan orang tua. Dapat dilihat dari tabel berikut ini rata rata pendapatan orang tua siswa kelas XI IPS.

Tabel 2. Rata - rata Pendapatan Orang Tua Siswa di SMA N 12 Sijunjung.

\begin{tabular}{lllcc}
\hline No. & \multirow{2}{*}{ Pekerjaan } & \multicolumn{1}{c}{ Tingkat penghasilan orang tua } & $\begin{array}{c}\text { Jumlah } \\
\text { Siswa }\end{array}$ & $\begin{array}{c}\text { (\%) penghasilan } \\
\text { orang tua }\end{array}$ \\
\hline 1 & Petani & Rp. 500.000-Rp. 1.500 .000 & 41 & 84 \\
2 & Wiraswasta & Rp. $1.600 .000-R p .2 .000 .000$ & 5 & 10 \\
3 & PNS & >Rp. 2.000.000 & 3 & 6 \\
\hline
\end{tabular}


Dari tabel 2 terlihat sebagian besar orang tua siswa yang ada di kelas XI IPS SMA Negeri 12 Sijunjung bekerja sebagai petani sebanyak $84 \%$, yaitu 41 orang siswa. wiraswasta $10 \%$ yaitu 5 orang siswa, dan PNS 6\% yaitu 3 orang siswa. Apabila dikaitkan dengan hasil belajar siswa maka terlihat bahwa untuk siswa yang orang tuanya yang berpenghasilan Rp. 500.000-Rp. 1.500.000 atau bekerja sebagai petani hasil belajarnya ada yang rendah dan ada yang tinggi, begitu juga dengan siswa yang orang tuanya yang berpenghasilan Rp. 1.600.000-Rp. 2.000.000 atau bekerja sebagai wiraswasta dan orang tuanya yang berpenghasilan $>$ Rp.2.000.000 atau bekerja sebagai PNS.

Peneliti juga melakukan observasi dan wawancara dengan 10 (sepuluh) orang siswa pada bulan Mei 2013 untuk mengetahui apalagi yang mempengaruhi rendahnya hasil belajar siswa kelas XI IPS di SMA N 12 Sijunjung. Berdasarkan observasi yang peneliti lakukan, 7 (tujuh) orang siswa menyatakan bahwa orang tua mereka jarang memberikan perhatian bagai mana proses belajar mereka, seperti menanyakan bagaimana hasil belajar mereka disekolah. Maka dari itu peneliti menduga perhatian orang tua juga dapat mempengaruhi hasil belajar siswa.

\section{Pengertian Hasil Belajar}

Menurut Hamalik (2008:30) mengemukakan tentang pengertian hasil belajar."Hasil belajar adalah tingkah laku yang baru, tingkah laku yang baru misalnya dari tidak tahu menjadi tahu, timbulnya pengertian baru, perubahan dalam sikap, kebiasaan, keterampilan, kesanggupan, menghargai perkembangan sifat-sifat sosial ekonomi emosional dan pertumbuhan jasmani." Syah (2008: 150) berpendapat bahwa hasil belajar ideal meliputi segenap ranah psikologis yang berubah sebagai akibat pengalaman dan proses belajar siswa. Selanjutnya menurut Caroll (Sudjana 2008: 40), hasil belajar yang dicapai siswa di pengaruhi oleh lima faktor, yakni (1) bakat belajar, (2) waktu yang tersedia untuk belajar, (3) waktu yang dibutuhkan siswa untuk menjelaskan pelajaran, (4) kualitas pengajaran, dan (5) kemampuan individu.

\section{Perhatian Orang Tua}

perhatian orang tua menurut Suryabrata (2005:14), 1) perhatian adalah pemusatan tenaga psikis tertuju pada suatu objek. 2) perhatian adalah banyak sedikitnya kesadaran yang menyertai suatu aktivitas yang dilakukan. Selain itu Slameto (2003: 105) juga menjelaskan perhatian adalah kegiatan yang dilakukan seseorang dalam hubungannya dengan pemilihan rangsangan yang datang dari lingkungannya. Rangsangan dari lingkungan dapat berupa pembuatan dan keadaan yang membutuhkan konsentrasi yang akan terpecahkan setelah diadakan penglihatan.

\section{Pendapatan Orang Tua}

Menurut Sumardi dan Evers (1993:92) pendapatan dapat berupa uang dan barang, pendapatan berupa uang adalah segala penghasilan berupa uang yang sifatnya reguler dan yang diterima biasanya sebagai balas jasa atau kontra prestasi. Pendapatan berupa barang adalah segala penghasilan yang sifatnya reguler dan biasa akan tetapi tidak selalu berbentuk balas jasa dan diterimakan dalam bentuk barang atau jasa.

\section{METODE PENELITIAN Jenis Penelitian}

Berdasarkan permasalahan dan tujuan penelitian yang ingin dicapai, maka jenis penelitian ini adalah berupa penelitian kuntitatif, yaitu penelitian yang menggunakan data berupa angka-angka dengan hasil analisa yang disajikan berupa angka-angka (matematis) yang kemudian diuraikan/dijelaskan atau diinterpretasikan dalam suatu uraian Mahmud (2011:29).

\section{Populasi}

Menurut Sedarmayanti (Mahmud 2011:121) populasi merupakan himpunan keseluruhan karakteristik dari objek yang diteliti. Populasi penelitian ini adalah orang tua dan siswa di SMA Negeri 12 
Sijunjung. Berdasarkan data yang di dapat maka jumlah populasi dalam penelitian ini adalah seluruh siswa kelas XI IPS yang terdiri dari 2 (dua) lokal yang berjumlah 49 orang siswa.

\section{Sampel}

Menurut Sedarmayanti (Mahmud 2011:121) sampel merupakan bagian dari populasi yang diambil melalui cara cara tertentu yang juga memiliki karakteristik tertentu, jelas dan lengkap yang dianggap bisa mewakili populasi. Berdasarkan pendapat tersebut maka teknik pengambilan sampel yang digunakan yaitu total populasi sampling, yaitu seluruh populasi dijadikan sampel. Dengan demikian jumlah responden penelitian ini adalah sebanyak 49 orang siswa.

\section{Sumber Data}

\section{Sumber data primer}

Sumber data dalam penelitian ini adalah siswa SMA N 12 Sijunjung, yang terpilih sebagai kelas sampel yaitu tentang pengaruh perhatian dan pendapatan orang tua terhadap hasil belajar siswa.

\section{Sumber data sekunder}

Sumber data dalam penelitian ini adalah hasil belajar ekonomi siswa Sekolah Menengah Atas 12 Sijunjung yang terpilih sebagai responden.

\section{Definisi Operasional}

Untuk lebih mempermudah dalam penelitian ini dan untuk menghindari penafsiran yang berbeda pada penelitian ini, maka penulis perlu menjelaskan definisi operasional variabel sebagai berikut:

1. Perhatian orang tua (X1) yang dimaksud dalam penelitian ini yaitu keadaan dan kegiatan yang dilakukan oleh orang tua dalam menyertai kegiatan belajar anaknya. Perhatian orang tua dinilai dengan menggunakan indikator sebagai berikut:
a. Mendampingi anak saat belajar
b. Memperhatikan anak saat belajar
c. Memberikan pengarahan pada anak

d. Memberikan peringatan pada anak

e. Melakukan kontrol pada aktivitas belajar anak

f. Memberikan dukungan kepada anak

g. Memberikan penghargaan kepada anak

h. Menjadi teladan yang baik

i. Memberikan perlakuan yang adil terhadap anak

2. Tingkat pendapatan orang tua (X2) yang dimaksud dalam penelitian ini adalah hal-hal yang berkaitan dengan penghasilan orang tua atau pendapatan orang tua. Pendapatan orang tua dinilai dengan menggunakan indikator sebagai berikut:

a. Golongan sosial ekonomi sangat tinggi

b. Golongan sosial ekonomi tinggi

c. Golongan sosial ekonomi sedang

d. Golongan sosial ekonomi rendah

3. Hasil belajar (Y) yang dimaksud dalam penelitian ini adalah perubahan didalam pikiran dan tingkah laku individu juga perubahan yang ditimbulkan aktivitas belajar, dengan indikator hasil belajar pelajaran ekonomi siswa.

\section{Teknik Analisa Data Analisis Deskriptif}

Analisis deskriptif bertujuan untuk menggambarkan atau melukiskan masing masing variabel yang nantinya berbentuk data yang disajikan dalam bentuk tabel distribusi frekuensi.

\section{Analisis Induktif}

a. Uji Asumsi Klasik

1) Uji Normalitas

Analisis uji normalitas dalam penelitian bertujuan untuk mengetahui apakah data berdistribusi normal atau tidak. Pengujian normalitas menggunakan uji kolmogrov smirnov dengan bantuan SPSS 16. 
Hasil uji normalitas $=(n=49)(p=5 \%)$

\begin{tabular}{lllll}
\hline No & Variabel & KS & Sig & Keterangan \\
\hline 1. & Hasil Belajar $(\mathrm{Y})$ & 1,282 & 0.075 & Normal \\
2. & Perhatian Orang Tua $\left(\mathrm{X}_{1}\right)$ & 0,894 & 0.401 & Normal \\
3. & Pendapatan Orang Tua $\left(\mathrm{X}_{2}\right)$ & 1,116 & 0.166 & Normal
\end{tabular}

Sumber: Pengolahan Data SPSS, 2013

\section{Uji Heteroskedastisitas}

Uji heteroskedastisitas adalah untuk melihat apakah model memiliki varian residu yang sama. Menurut Santoso (2000:210) cara untuk mengamati terjadinya heterokedastisitas dapat dilihat dari scatter plot. Jika pada grafik tampak titik-titik yang menyebar di atas dan di bawah sumbu $\mathrm{Y}$, dan tidak terjadi pola tertentu atau tidak ada pola yang sistematis, maka dapat disimpulkan bahwa tidak terjadi heteroskedastisitasdan sebaliknya.

\section{Hasil Uji Heteroskedastisitas}

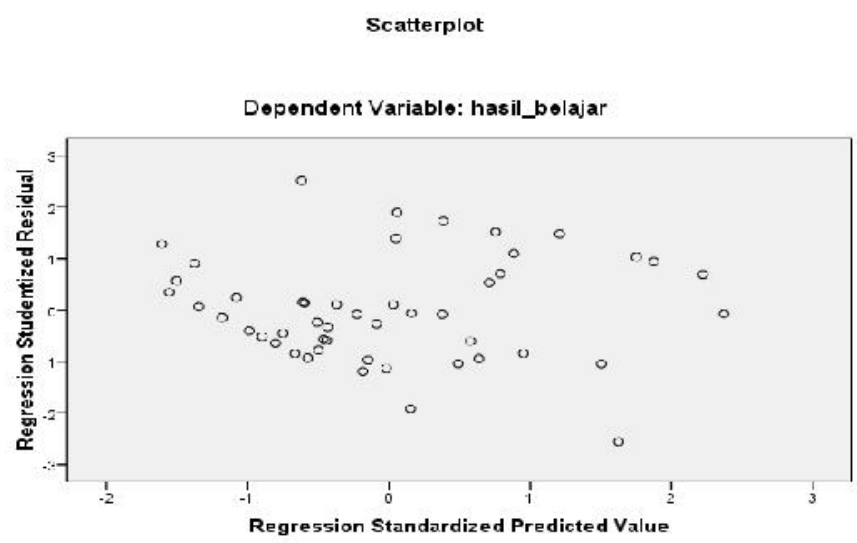

\section{Uji Multikolinearitas}

Analisis ini bertujuan untuk melihat korelasi sesama variabel bebas. Apabila terdapat korelasi yang tinggi sesama variabel, maka salah satu diantaranya dieliminir (dikeluarkan dari regresi berganda). Untuk menentukan ada atau tidaknya multikolinearitas dilakukan dengan metode besaran VIF (Variance Inflasion Factor).

\section{Hasil uji Multikolinearitas}

\begin{tabular}{lllll} 
& & \multicolumn{3}{c}{ Collinearity Statistics } \\
\cline { 3 - 5 } Model & & Tolerance & VIF \\
\cline { 3 - 5 } 1 & Perhatian & & .972 & 1.028 \\
& pendapatan & .972 & 1.028 \\
\hline
\end{tabular}

Sumber: Hasil Pengolahan Data Primer 2013

\section{Uji Autokorelasi}

Analisis autokorelasi merupakan analisis yang digunakan untuk mengetahui 
ada tidaknya korelasi antara anggota observasi satu dengan observasi lainnya yang berlainan waktu.

\section{Hasil Uji Autokorelasi}

\begin{tabular}{lrrrrr} 
Model & R & R Square & $\begin{array}{c}\text { Adjusted R } \\
\text { Square }\end{array}$ & $\begin{array}{c}\text { Std. Error of the } \\
\text { Estimate }\end{array}$ & Durbin-Watson \\
\hline 1 & $.794^{\text {a }}$ & .631 & .615 & 3.89351 & 2.489 \\
\hline
\end{tabular}

Sumber: Hasil Pengolahan Data Primer, 2013

\section{Uji Regresi Linear Berganda}

1) Uji t

Uji $\mathrm{t}$ dilakukan untuk mencari pengaruh variabel bebas terhadap variabel terikat secara parsial dengan mengasumsikan variabel lain di anggap konstan.

\section{2) Uji F}

Pengujian ini bertujuan untuk melihat pengaruh secara bersama sama antara variabel bebas terhadap variabel terikat atau menguji hipotesa mayor. Pengujian ini dilakukan dengan membandingkan nilai $F_{\text {hitung }}$ dengan $F_{\text {tabel }}$.

\section{3) Analisis $R^{2}$ (Determinasi)}

Koefisien

determinasi

$\left(R^{2}\right)$ digunakan untuk menentukan besaran kontribusi variabel bebas dalam menjelaskan variabel terikat. Hasil pengujian koefisien mencerminkan pengukuran koefisien determinasi $\left(R^{2}\right)$ untuk melihat pengaruh dari variabel bebas terhadap variabel terikat. Untuk menghitungnya juga dibantu dengan menggunakan program SPSS.

\section{PEMBAHASAN}

\section{Pengaruh perhatian orang tua terhadap hasil belajar siswa}

Berdasarkan uji hipotesis diperoleh

hasil, bahwa perhatian orang tua berpengaruh secara signifikan dan positif terhadap hasil belajar siswa. Hal ini dapat dibuktikan dengan hasil penelitian yang menyatakan bahwa nilai $t_{\text {hitung }}>t_{\text {tabel }}$ yaitu 2,819>2,021 dan nilai Sig sebesar $0,007<\alpha=0,05$, dan nilai koefisien regresi linear berganda $b=X 1(0,170)$, hal ini berarti bahwa semakin tinggi perhatian orang tua akan berdampak semakin tinggi pula hasil belajar siswa, begitu juga sebaliknya apabila perhatian orang tua rendah maka hasil belajar siswa juga akan rendah, dapat berdampak terhadap hasil belajar siswa. Hal ini sesuai dengan pendapat Dalyono (2010:59) faktor orang tua sangat besar pengaruhnya terhadap keberhasilan anak dalam belajar.

\section{Pengaruh pendapatan orang tua terhadap hasil belajar siswa}

Berdasarkan uji hipotesis diperoleh hasil, bahwa pendapatan orang tua berpengaruh secara signifikan dan positif terhadap hasil belajar siswa. Hal ini dapat dibuktikan dengan hasil penelitian yang menyatakan bahwa nilai $t_{\text {hitung }}>t_{\text {tabel }}$ yaitu 7,131 > 2,021, dan nilai Sig sebesar $0,000<\alpha=0,05$, dan nilai koefisien regresi linear berganda $b=X 2(0,155)$, hal ini berarti bahwa semakin tinggi pendapatan orang tua akan berdampak semakin tinggi pula hasil belajar siswa, begitu juga sebaliknya apabila pendapatan orang tua rendah maka hasil belajar siswa juga akan rendah. Hal ini sesuai dengan pendapat Ahmadi (2007:230) menyatakan bahwa status sosial ekonomi orang tua mempunyai pengaruh terhadap tingkah laku dan pengalaman anak anaknya.

\section{Pengaruh perhatian dan pendapatan orang tua terhadap hasil belajar siswa \\ Penelitian ini bertujuan untuk} mengetahui pengaruh secara bersama-sama antara perhatian dan pendapatan orang tua terhadap hasil belajar siswa. Berdasarkan analisis data dan pengujian hipotesis yang 
telah dilakukan dalam penelitian ini diperoleh nilai $F_{\text {hitung }}>F_{\text {tabel }}$ yaitu 39,276 $>3,23$, dan nilai Sig $0,000<\alpha=0,05$. Hal ini menunjukkan bahwa perhatian dan pendapatan orang tua berpengaruh secara signifikan dan positif terhadap hasil belajar siswa. Semakin tinggi perhatian dan pendapatan orang tua maka akan semakin tinggi pula hasil belajar siswa. Berdasarkan analisis diatas dan hasil penelitian terlihat jelas perhatian dan pendapatan orang tua berpengaruh signifikan terhadap hasil belajar siswa. Kemudian hasil koefisien determinan $\left(\mathrm{R}^{2}\right)$ juga menunjukkan bahwa perhatian dan pendapatan orang tua memberikan sumbangan terhadap hasil belajar siswa sebesar 0,631 atau 63,1\%. Sedangkan sisanya sebesar $36,9 \%$ disumbangkan oleh variabel lain diluar penelitian ini.

\section{PENUTUP}

\section{Kesimpulan}

Berdasarkan hasil analisis yang berkaitan dengan tujuan penelitian ini, maka dapat ditarik beberapa kesimpulan hasil penelitian sebagai berikut:

1. Perhatian orang tua berpengaruh signifikan dan positif terhadap hasil belajar siswa. Hal ini ditunjukan oleh nilai koefisien uji $t_{\text {hitung }}>t_{\text {tabel }}$ yaitu 2,819> 2,021, berarti bahwa semakin tinggi perhatian orang tua maka akan semakin meningkat pula hasil belajar siswa.

2. Pendapatan orang tua berpengaruh signifikan dan positif terhadap hasil belajar siswa. Hal ini ditunjukan oleh nilai koefisien uji $t_{\text {hitung }}>t_{\text {tabel }}$ yaitu 7,131> 2,021, berarti bahwa semakin tinggi pendapatan orang tua maka akan semakin meningkat pula hasil belajar siswa.

3. Perhatian dan pendapatan orang tua secara bersama-sama berpengaruh signifikan dan positif terhadap hasil belajar siswa.Hal ini ditunjukan oleh nilai koefisien uji $F_{\text {hitung }}>F_{\text {tabel }}$ yaitu $39,276>3,23$ berarti bahwa dengan perhatian orang tua yang tinggi dan pendapatan orang tua yang menunjang untuk memenuhi fasilitas belajar maka akan mampu mempengaruhi hasil belajar siswa.

Sedangkan kontribusi kedua variabel bebas perhatian dan pendapatan orang tua terhadap hasil belajar cukup besar yang ditunjukan oleh nilai koefisien determinasinya $\mathrm{R}^{2}$ sebesar 0,631 atau $63,1 \%$ yang berarti sumbangan yang diberikan oleh perhatian dan pendapatan orang tua terhadap hasil belajar siswa kelas XI di SMA N 12 Sijunjung ada sebesar $63,1 \%$. Sedangkan sisanya sebesar $36,9 \%$ disumbangkan oleh variabel lain diluar penelitian ini.

\section{Saran}

Berdasarkan kesimpulan di atas, maka dapat diajukan beberapa saran, antara lain:

1. Diharapkan kepada orang tua siswa untuk lebih memperhatiakan anaknya mengenai masalah kependidikannya, seperti mendampingi anak saat belajar, memperhatikan anak saat belajar, memberikan pengarahan pada anak, memberikan peringatan pada anak, melakukan kontrol pada aktivitas belajar anak, memberikan dukungan kepada anak, memberikan penghargaan kepada anak, menjadi teladan yang baik, memberikan perlakuan yang adil terhadap anak

2. Diharapkan kepada orang tua siswa untuk lebih memenuhi kebutuhan siswa, seperti alat tulis belajar siswa, kelengkapan sarana dan prasarana anak untuk sekolah dan belajar agar hasil belajar siswa dapat meningkat.

\section{DAFTAR PUSTAKA}

10.22202/economica.2013.v2.i1.212

Ahmadi, Abu. 2003. Ilmu Sosial Dasar. Jakarta: PT. Rineka Cipta 
2007. Psikologi Sosial. Jakarta: PT. Rineka Cipta

Arikunto, Suharsimi. 2002. Prosedur Penelitian Suatu Pendekatan Praktek. Jakarta: Rineka Cipta

Anwar, Syafri. 2009. Penilaian Berbasis Kompetensi. Padang: UNP Press Padang

Annurrahman. 2010. Belajar dan Pembelajaran. Bandung: Alfabeta

Badan Pusat Statistik (BPS). 2008. Pengeluaran Untuk KonsumsiPenduduk Sumatera Barat.

Dalyono. 2010. Psikologi Pendidikan. Jakarta: Rineka Cipta

Djaafar, Tengku Zahara. 2001. Kontribusi Strategi Pembelajaran Terhadap Hasil Belajar. Padang: Fakultas Ilmu Pendidikan UNP Padang

Efriman. 2007. Korelasi Sosial Ekonomi Orang Tua Terhadap Hasil Belajar Siswa Kelas III MAN I Lembah Melintang Kabupaten Pasaman Barat. Padang

Hamalik, Oemar. 2008. Proses Belajar Mengajar. Jakarta: PT. Bumi aksara

Herif, Febrian. 2001. Pengaruh Pendapatan Orang Tua dan Motivasi Belajar Terhadap Hasil Belajar Mata Kuliah Bidang Studi (MKBS) Mahasiswa Program Studi Pendidikan Ekonomi. Fakultas Ekonomi UNP

Irianto, Agus. 2010. Statistik Konsep Dasar, Aplikasi dan Pengembangannya. Jakarta: Prenada Media Group

Mahmud. 2011. Metode Penelitian Pendidikan. Bandung: CV. Puataka Setia

Nashori, Fuad. 2005. Profil orang tua anak-anak berprestasi. Yogyakarta: Insania Citra Press

Riduwan. 2010. Belajar Mudah Penelitian. Bandung: Alfabeta

Sanjaya, Wina. 2006. Strategi pembelajaran berorientasi standar proses pendidikan. Bandung: Prenada Media Group.

Santoso, Singgih. 2000. SPSS Statistik Parametrik. Jakarta: PT. Gramedia

Slameto. 2003. Belajar dan faktor faktor yang mempengaruhinya. Jakarta: Rineka Cipta

Shadly. 1979. Ensiklopedi Indonesia

Soemanto, Wasty. 2006. Psikologi Pendidikan. Jakarta: Rineka Cipta

Sudjana, Nana. 2008. Dasar-dasar Proses Belajar Mengajar. Bandung: Sinar Baru Algensindo

Sumardi, Mulyanto dan Evers, Hans Dieter. 1993. Kemiskinan Dan Kebutuhan Pokok. Jakarta: CV. Raja Wali

Susanti. 2001. Badan Pusat Statistik

Sunarto. 2009. Factor Factor Yang Mempengaruhi Hasil Belajar. http//www. harminingsih.blogspot. com. Diakses tanggal 4 bulan April 2013

Suryabrata, Sumadi. 2005. Psikologi Pendidikan. Jakarta: PT Raja Grafindo Persada

Sukirno, Sadono. 2004. Makro Ekonomi Teori Pengantar. Jakarta: PT Raja Grafindo Persada

Syah, Muhibbin. 2008. Psikologi pendidikan dengan pendekatan baru. Bandung. PT. Remaja Rosda Karya

Tim penyusun bahan ajar belajar dan pembelajaran. 2004. Belajar dan Pembelajaran. Padang: Fakultas Ilmu Pendidikan UNP

Umar, Husein. 2011. Metode Penelitian Untuk Skripsi Dan Tesis Bisnis. Jakarta: PT. Raja Grafindo Persada.

Yani, Linda Eka Putri . 2009. Hubungan factor social ekonomi keluarga terhadap hasil belajar geografi siswa kelas XI di SMA N 1 Kecamatan Padang ganting kabupaten tanah datar 